\title{
TRANSGRESSIIVNE KIVISILDNIK - 2019. AASTA SEISUGA, OLULIST
}

\author{
JANEK KRAAVI
}

$\mathrm{K}$ ivisildnik on piiride ületaja õpikunäide. Esteetiliste ja eetiliste kokkulepete korduv rikkumine moodustab lahutamatu osa tema autoriKinnistunud mentaliteetide mõrandamist, ambivalentset suhtumist traditkinnistunud mentaliteetide mõrandamist, ambivalentset suhtumist traditsioonilisse kirjandusse ja kirjanduse piiridesse, isegi elementaarsete viisakusreeglite eiramist. XX sajandi lõpukümnendil ilmunud Kivisildniku tekste olengi põgusalt vaadelnud transgressiivse kirjanduse seisukohalt (vt Kraavi 2016: 822-824, 2017: 45, 65). Käesoleva artikli eesmärgiks on pöörata tähelepanu piire ületavatele troopidele ja võtetele (nt karneval, räusk, jeremiaad, religioonitõlgendus) Kivisildniku uuemas luules ja nullindate publitsistlikus proosas ning vastata transgressiivse poeetika kontekstis küsimusele, miks kriitika on Kivisildniku viimaste aegade loomingust mõneti mööda vaadanud või miks on vastuvõttu tunginud tugev irooniline hoiak. 1990. aastatel pakkusid tema kirjanduslikud eksperimendid huvi kirjandusteadlastele, samavõrra jätsid tavalisele kultuurihuvilisele kustumatu mälestuse Kivisildniku kirjandusliku tegevuse tagajärjel kirjandusest väljapoole küündinud skandaalid. Kuigi praegu ilmub aastas kolm kuni neli (:)kivisildniku kaubamärki kandvat raamatut, on kunagine elevus ometi kadunud. Jätame praegu kõrvale asjaolu, et sellise tootlusega ei suuda sammu pidada ükski kultuuriväljaanne ega arvustaja. Sisulisemas plaanis võiks vastuseid otsida muutunud poliitilisest õhustikust ja uue meedia teistmoodi toimeväljast, mille tagajärjel on ümber paigutunud ideoloogilised positsioonid ning ootamatus suunas on liikunud ka sotsiaalse ja esteetilise välja vahelised suhted. Siit hargnevate teemade ja kujundite juurde pöördun tagasi pärast sissejuhatavat ülevaadet, milles kaardistan kõigepealt varasema Kivisildniku suhte transgressiivse kirjandusega.

Kõike Kivisildnikku puutuvat üle korrata pole siinkohal põhjust: „tuhandete lemmiku" ja eesti kirjanduskriitika vahelisi suhteid demonstreerib suurejooneliselt kriitikakogumik „Kivisildnik, põhjendamatu järjekindluse dogmaatik" (2016, edaspidised viited kogumikus ilmunud artiklitele KPJD). Juba eessõnas rõhutab Neeme Lopp kõnealuse autori loomingut saatva häire või negatiivsuse tähendust loovat jõudu: „Vea produktiivsus seisneb selles, et kultuur peab sellise tõrke ilmnemisel oma sümboolsed ruumid mingil moel ümber korraldama" (KPJD: 6). Raamatu ligemale kolmkümmend kirjutist tegelevadki Kivisildniku loomingu sissekirjutamisega kultuuriruumi ja kirjandusajalukku ning loomuldasa esineb nendes käsitlustes kokkupuutepunkte ka kunstilise transgressiivsuse märksõnade või kriitilise mõistestikuga.

Näiteks Andres Langemetsa artikkel 1990. aastate keskpaigast kõneleb kunstniku vabadusest, mille ajel „ületatakse kunstilistes tekstides muu 
ühiskonna jaoks lubamatuid kõlbelisi ja isegi juriidilisi norme” (KPJD: 51). Samal ajal jääb kriitik normide ületamist selgitades pidama elu ja kunsti range opositsiooni juures ega defineeri piiri olemust või piiri ületamise ideed, v.a kriminaalkaristusele viitav hoiatus. Olulise tunnusena toob Langemets välja modernistlike kunstiskandalistide poliitilise tegevuse, mis siiski piirdub üksnes marksismi äramainimisega. (KPJD: 51-52) Kivisildniku modernismijärgset ideoloogiliste tähistajate vabamängu esialgu ei märgatud. 1990. aastatel käsitleti ka Kivisildniku avangardset karnevalipoliitika formaati, kus iroonia, paroodia ja groteskiesteetika vaidlustavad piiri mõiste ja loovad potentsiaalse ruumi normide rikkumiseks (nt KPJD: 13-18). Korduvalt on mainitud skandaali-esteetika märksõnu (sündmus, solvamine, šokeerimine jms) ja revolutsionääri kuvandit - needki sobituvad kenasti transgressiivse kunsti paradigmasse (vt Kraavi 2016: 822-824).

Arne Merilai on sajandilõpul varase Kivisildniku uudsust selgitades võtnud võrdlusaluseks 1990. aastate avangardse kunsti transgressori Oleg Kuliku koermehe kontseptsiooni (KPJD: 81). „Transgressiivset võllanalja” on oletanud Hasso Krull raamatu „Nagu härjale punane kärbseseen” (1996) välisilmest ja kujundusest kõneldes (KPJD: 62), kuid sisuliselt jõuab ta piire ületava tehnika kirjeldamiseni romaani „Nagu isane kass ümber isase pudru” (1996) juures, kus religioosne diskursus paljastab ümberpööramise kaudu oma hämara tungilisuse. Kivisildniku taotluseks on lüüa diskursiivsesse reaalsusse mõra, kiskuda lahti lõhe, millest meile äkki avaneks Reaalne ilma ühegi sümboolse maskeeringuta. Nõnda on tema tekst suguluses õuduslugude, death-metal'i ja Vana Testamendi prohvetitega. (KPJD: 69-70)

2010. aastate lõpus sedastab Lauri Kitsnik haiku-traditsiooni ja pühaliku looduslüürika taustal luulekogu „Sumo” (2007) arvustades, et Kivisildniku eesmärgiks on see, et „[k]õik potentsiaalselt ilus tuleb ära rikkuda” (KPJD: 113). Nõnda asetuvad Kivisildniku tekstid ka inetuse esteetika raamidesse, kõigi sinna kuuluvate argipäevasuste, obstsöönsuste, jälestuse ja pilaga. Kitsnik nimetab seda „metafoori sekulariseerivaks ümberpööramiseks” (KPJD: 114), kus looduskujundit kasutatakse tarbimisühiskonna rutiini kummastamiseks.

Nimetatud kogumiku värskemad käsitlused 2010. aastate keskpaigast jõuavad transgressiivse momendi äratundmisel veelgi täpsemate hinnangute ja kirjeldusteni. Sekulariseeritud objekti esiletulekuga haakub Hasso Krulli käsitlus Kivisildniku traumaatilisest realismist. See lähtub sotsiaalse realismi ideest ehk kõigest sellest, mis on ühiskonnas vastik, inetu ja ebameeldiv. „Varasemast kriitilisest realismist erineb ta peamiselt selle poolest, et stressi, depressiooni, valu ja viletsuse kujutamine on justkui väärtus iseeneses, mitte mingi utoopilise ideaali pahupool" (KPJD: 191). Kivisildniku hoiakut iseloomustab seega reaalsuse traumaatilise tuuma tabamise vajadus, mida edaspidi korratakse kui traumaatilist tõde (KPJD: 193). Kindlasti võib see mõjuda häiriva ja vaikimisi kokkulepitud representatsiooni piiridest üleastumisena, sundmõttelise või ebaviisakana. Üleastumise poeetikat puudutab ka Neeme Lopp, kes näeb programmilisena vastandumisstrateegiat ja provokatsiooni, kuid osutab ka kriitika nõrgale kohale. Kivisildniku transgressiivsete tekstide vaim taandatakse esteetikale, kuid nii välistatakse transgressiooni objekt ja eetika (KPJD: 149-150). Transgressiivsust väljendavad ka erinevad ümberpööramisvõtted ja paradokside kasutamine ning nendel rajanev anti- 
humanistlik ideoloogia, mis omakorda toetub ökoterroristlikule hävingu metafoorile (vt KPJD: 160-163).

Mart Kangur jõuab Kivisildniku uusimas loomingus esinevaid sõjamotiive analüüsides järeldustele, et teatavatel tingimustel lunastab traditsioonilisest kunstnikupositsioonist loobumine „kommentaariumisõimu ja paremjauramise”, kuid autor riskib sellega, et kunstiline sõna „muutub robustseks ja lamedaks, ilma igasuguse kujundlikkuseta ärplemiseks, millel puudub nüüd ka faktuaalse lausumise pretensioon" (KPJD: 171). See oht puudutabki Kivisildniku viimaste aastate autorihoiakut, mille dominandiks on rahulolematus ja kriitiline pila, aga see asetub sajandivahetusega võrreldes muutunud ühiskondlikku mõtteruumi. Aare Pilv nimetab seda 1990-ndate tagasitulekuks farsina: „[---] tollane radikaalne kontseptualist Kivisildnik on muutunud lihtsalt poliitiliseks hüsteerikuks [---]" (Pilv 2016). Esteetika ja poliitika põimumine kahtlaselt antihumanistlikul moel on transgressiivse esteetika üks poolus, kuid seda võimendab lõhestunud ühiskond ja teisenenud kommunikatsiooni problemaatika. Selle pinnalt sünnib ka paremkonservatiivne transgressiivsuse tunnetus ning muutused sellesisulise kunsti olemuses ja vastuvõtul.

\section{Transgressor}

Kivisildniku varasem transgressiivsus, mida esindab eeskätt kaksikvärss „mul on kästud / kusta teie kaevu” (Kivisildnik 1996: 26), väljendab uusaja maailma mässumeelsust. Vastumõtlemise positiivne ja tähenduslik traditsioon oli kujunenud Euroopa kultuuris varem, aga kultuurilisi suundumusi mõjutav hoiak sai sellest XVIII sajandi teisel poolel: „Moraalse transgressori kui kangelasliku indiviidi kultus ulatub romantismiajastusse" (Nagle 2017: 31). Kangelase või geeniuse kontseptsiooni juurde kuuluv transgressiooniloogika tähendab pidevat vajadust individuaalsust kinnitava kogemuse, tundmata naudingute või revolutsiooniliste muutuste järele. See on institutsiooni ja indiviidi eneseteadvuse vaheline konflikt (Kaiser 2004: 11), mille väljundiks on kohati prohvetlikkuseni küündiv radikaalne poliitiline meelsus, apokalüptilised tulevikuvisioonid jms. ${ }^{1}$ Erandlikkust eneseloomes, kunstis ja ühiskondlikus elus on Kivisildnik manifesteerinud algusest peale, intensiivsemalt jätkub see uuemates kirjutistes, kus minakujund täidetakse massist eristumise, eneseülendamise, õpetamise või valitsemise motiivi kandva moraaliga, kusjuures n-ö tavainimeste käitumiskood selgelt välistatakse: „kui ma oleksin / osa sellest ühiskonnast / siis ma vabandaksin” (Kivisildnik 2012a: 12).

Romantismiajastu subjektiivse enesekehtestamise jõuline taastulek toimus XX sajandi modernistlikus avangardis, kuid saavutas suurema intensiivsuse 1960. aastate kontrakultuuris. Postmodernistlikus kunstiparadigmas muutus transgressioon oluliseks esteetiliseks jõuks, mida liberaalne kunstikriitika oli sunnitud käsitlema justkui enesestmõistetavalt positiivse nähtusena. „Professionaalsed kriitikud on seepärast pidanud seisma silmitsi väljakutsega, kas toetada transgressiooni tingimusteta või mõista see hukka ning riskida vanameelsusse kaldumisega ja kahtlustustega konservatiivsu-

\footnotetext{
${ }^{1}$ Romantismiajastu poliitilise ja esteetilise akti eriomase seotuse kohta vt nt Frye 1963 või kriitiline lühiülevaade Day 2001: 85-105.
} 
ses" (Cashell 2009: 1). Originaalsuse ja erakordsuse auraga ümbritsetud kontseptuaalne transgressiivsus iseloomustab Kivisildniku kogu varast loomingut, mis algusest peale on klassikalise avangardi vaimus tegelenud otseselt moraali ja eetika ümberpööramisega esteetiliseks võimalikkuseks. Kunagised põlvkondadevahelised vastuolud või vormiotsingud on 2010. aastatel asendunud poliitilise sisuga moralistlike sõnavõttudega: varasemale kapitalismi kriitikale on lisandunud sõjaohu ja vägivalla estetiseerimine, rahvustemaatika ja paremideoloogia poole kalduv enesepositsioneerimine. Kuid järjest äärmuslikumaid väljaütlemisi sisaldavas ühiskondlikus õhustikus saab nende teemadega töötav transgressor varasemast tunduvalt leigema vastuvõtu osaliseks.

XXI sajandi alguses olid asjalood mõnevõrra teistmoodi. Kivisildniku tollast poliitilist proosat koondava raamatu „Null tolerants” (2004) tiitellehele eelneb paratekst pealkirjaga „Ekstreemkirjanduse manifest”. Lugeja ootusi väga jõuliselt suunavas tekstis kuulutatakse eesti kirjandus „nüriks nühkimiseks” ja deklareeritakse: „Publik tahab näha surmasaltosid, känkarasse kukkuvaid kehasid ja kangelasi, kes murravad sada konti ja ei tee teist nägugi.” Ekstreemkirjandus peaks seega sisaldama meelelahutust ja koomiksiesteetikat, mille kaudu naeruvääristada poliitikuid ja avaliku elu tegelasi, kusjuures väljendusviisi poeetilisteks dominantideks oleksid nulltolerants ja otseütlemine. „Null tolerants” on enamjaolt meediaajastu poliitilise diskursuse kriitika paroodiliste portreede vormis. Raamatu põhivõteteks on isiklik solvang ja mõnitamine, eesmärgiga madaldada konkreetse isiku sotsiaalset staatust. Paljudel juhtudel tähendab see füsioloogia, kehakuju või näojoonte inetuse rõhutamist: „[---] tal on kõik kaagile vajalikud tunnused: vilav pilk, tömp koon ning degenerandi kõrv. Paljud klassikalised kultuurid omistavad kõrvanibuta tegelastele vaimsete võimete puudumist ja sellest johtuvat vägivaldsust." (Kivisildnik 2004: 7) Mõnitamist täiendab rõhutatud maskuliinne pilk: „Vaadata pole midagi ja katsuma ka eriti ei kisu, ehk siis pärast viitteist õlut. Vilja pole ei silmapaistev iludus ega miski mõttehiiglane, hädapärast annab kvaliteettabloidi kaheteistkümnenda lehekülje mõõdu välja." (Kivisildnik 2004: 52) Leiab ka juudivastast hoiakut ja rikaste vaenamist, Edgar Savisaare ja Keskerakonna kriitikat, samuti vilksatab korduvalt kultuurkapitali tegemisi osatav küüniline kommentaar. Algselt ajalehes KesKus ilmunud tekstid eristusid tollasest üldisest avalikust arvamusest oma terava ja ründava tooni poolest, olles reaktsioon poliitikute sigadustele ja arrogantsile. Kuid neid hea maitse ja häbematuse piiril balansseerivaid tekste saaks käsitleda ka alamaid ja valitsejat eraldava diskursuse mahalõhkumisena karnevalimudeli raames.

\section{Karneval 2.0}

Karneval kui lääne kultuurile üldomane satiiritraditsioon paistab koomiliste žanrite seast silma ebatsensuurse sõnakasutuse ja piire ületava subjektikäsitluse poolest. Postmodernistliku paroodia, vabastava naeru ja karnevali kontekstis on Kivisildniku tekstidele ja tegudele osutanud Piret Noorhani ja Kajar Pruul (vt KPJD: 17-18, 44). Transgressiivsuse uuringud avastavad karnevalidiskursuse pingetest vabastava meelelahutuslikkuse kõrvalt avarama tähendusvälja, mille raamiks on „põhimõtteline ja hävitamatu mitteametlikkus” 
(Bahtin 2017: 9). Peter Stallybrass ja Allon White on karnevallikkust käsitlenud hierarhia ja hegemoonia vastase radikaalse transgressiooni vormina, mis ei ole ainult Euroopa kultuuri klassikaline rituaal, vaid kultuurianalüütiline „mõistmisviis”. See on protsess, kus inimkeha, psüühilised normid, geograafiline ruum ja sotsiaalne süsteem on konstrueeritud vastastikku mõjutavate ja sõltuvate hierarhiate sees. „Kõrge” ja „madal” või „ülemine” ja „alumine” on katkematus läbirääkimiste seisundis, st karneval pole üksnes alluvale omane rituaalne ülenemise praktika, vaid eelkõige ühiskondlike võimusuhete väljendus (Stallybrass, White 1986: 6). Karnevali on käsitletud stabiilse ja tsüklilise rituaalina, millel pole tegelikult märkimisväärset ühiskondlikku mõju, kuid terava poliitilise vastasseisu olemasolul võib see osutuda katalüsaatoriks ning tegeliku ja sümboolse võitluse väljaks (Stallybrass, White 1986: 14). Kuigi rahvakultuurilise praktikana on karneval marginaliseerunud, töötavad needsamad identiteediloome ja võimukriitika mehhanismid edasi nt kunstis ja eriti tänapäeva meedias. Kivisildnikus on esteetika ja meedia lahutamatult seotud ja nendevaheline piir sageli ähmastunud (vt ka KPJD: 133-134).

Kivisildniku looming on laiali laotunud eri meediavormides ja kultuuripraktikates (lisaks raamatutele tabloid- ja tavaajakirjandus, kultuuriajakirjandus, televisioon, performance'id ja ooperilavastus, reklaam, raadio, blogi, rollimängud, kirjastamine, sotsiaalmeedia jms). ${ }^{2}$ Kivisildnik oli ka esimene eesti kirjanik, kellel oli oma kodulehekülg, mis muuseas algas tutvustusega: "Tundke end kõigi aegade suurima eesti luuletaja juures vabalt" (vt Kauksi Ülle 2014: 96). Intensiivne oma „hääle” otsimine langes tsensuurivaba ajakirjanduse väljakujunemise aega, mil esimesi samme astus internetiga seonduv elektrooniline ja digitaalne meedia. Kuid see võimaldas ja eeldas hoopis uutmoodi rääkimist ja kirjutamist. Kajar Pruul täheldas paarikümne aasta eest lausa ettenägelikult: „[---] harjumatus meediasituatsioonis lõid vankuma senised arusaamad autentse teadmise võimalikkusest" (KPJD: 40). Avaliku kommunikatsiooni radikaalselt muutunud olemus sobib Kivisildniku provokatsiooniesteetikaga hästi kokku ka tänapäeval: hierarhilisuse pidev lammutamine, müstifikatsioonid, vastumõtlemine, väljamõeldud uudised on paradoksaalsel moel saanud informatsiooni ja narratiivide loomise tavapäraseks praktikaks.

Kodulehekülgede, arvutimängude, suhtluskeskkondade jm mõtestamisel on identiteet, sh anonüümsus, maskeraad ja etendamine väga kesksed ideed, millesse tänapäeval mahuvad küsimused osalejate võrgustikulisest ühendusest ja minaavalduste teistsugusest iseloomust. Kõigepealt pakuvad eri meediumid võimaluse identiteedi eri aspektide väljendamiseks. Varjunimelisus ja avataride kasutamine on kaasalöömine online-identiteedi karnevalil. Maskide kasutamine lisab kommunikatsiooni uue mängulisuse, mis võimaldab katsetada mina erinevate külgedega, võtta suheldes rohkem riske ning väljendada igapäevakõneluses võimatuna tunduvaid teemasid või minaaspekte (Lister jt 2009: 209-210). Tavasuhtluse piiride ümbermängimine ja ületamine on minapilti avardav tegevus, mille mängulisust rõhutati internetimeedia algusaegadel. Kuid virtuaalse ja reaalse ähmastumine kannavad ühiskondliku retoorika

${ }^{2}$ Enamik artikleid ja kommentaare on koondatud publitsistikakogumikesse, nt varasema perioodi ajakirjanduslikku tegevust kajastab mammutraamat „Valitud teosed I” (2004). 
ja minaväljenduse iseloomu järjest jõulisemalt piiridele, mille ületamine toob kaasa tugevad reaktsioonid ning agressiivsed seisukohavõtud. Eesti nüüdiskirjanduse virtuaalkogemusest võib näiteks tuua sajandi alguses internetiarutlusrühmas littera@lists.ut.ee puhkenud diskussiooni, mis järgnes elektroonilises kirjandusajakirjas ,et ilmunud Wimbergi natsismiteemalisele artiklile (vt Hasselblatt 2015). Tähelepanu võiks juhtida ka 2003. aasta märtsi alguses kirjanduslistis kirjandus@yahoogroups.com toimunud mõttevahetusele, kus Kivisildniku reaktsioon kirjandusauhindade teemal hülgas tavaviisakuse normid, millele järgnes eri osapoolte solvanguid, sõimu ja ähvardusi täis mõttevahetus. See on juba väga kaugel mängust või literatuursest karnevalist, kuna virtuaalses ruumis tekkiv distants vestluskaaslastega muudab mõtteavaldused ja tooni tavapärasest teravamaks ja väga isiklikuks (vt Vihik esitleb... 2004). Siin annab endast märku hoiak, mida on nimetatud ka „transgressiivsus 2.0". See tähendab varasemast erinevaid teksti tootmise, levitamise ja ringluse põhimõtteid. Selle tagajärjel kujuneb arusaam, et digiajastu meediat ümbritsevad vastuolud, mis ähvardavad meie seniseid arusaamu ajast ja ruumist, aga eelkõige näitab see suhtlusmustrites ja sotsiaalsetes struktuurides toimunud nihet, mis mõjub ähvardusena kehtiva võimu aadressil. (Gournelos, Gunkel 2012: 8) Interneti ja digitaalse suhtlusega seotud moraalses paanikas on täheldatud vastuolu, mis tekib uut energiat kandva avaliku sfääri ideaalide - teadlaste, akadeemikute, poliitikute ja tsiviliseeritud ühiskonna elektroonilise agoraa - ning võrgustiku tegeliku sisu vahel, mis on tulvil pornograafiat, pettust, poliitilist manipulatsiooni, jututubade rassismi, fanaatikuid ja ahistajaid. Viimasel kümnendil olemegi olnud tunnistajaks olukorrale, kus interneti utoopia on muutumas problemaatiliseks käitumist kujundavaks modulaatoriks (Parikka, Sampson 2009: 7).

Uue meedia mõjud ja uuskarnevallik transgressiivsus on tunnuslik ka Kivisildniku publitsistikakogumikule „(:)raadiopastor” (2011a), mis koondab 2010. aastate lõpus rahvusringhäälingu eetris kõlanud raadiokommentaare. Minakujuks on meediaevangelistidele viitav raadiojutlustaja, kelle (kultuuri)poliitikat kritiseerivad kommentaarid paistavad silma ülbe ja provotseeriva väljenduse ning lihtsustava teemakäsitluse poolest, kuid selles esteetikas on positsioonide ümberpööramisest ning seisuste sümboolsest tühistamisest tekkinud uued tähendused ja karnevalivastuolu. Konfliktsemad teemad puudutavad ebavõrdsust, vaesust ja rikkust, harimatust ja ahnust. See on kapitalismi ideede ümberpööramine, nõnda et nähtavale tulevad valitseva majandusmudeli ja maailmavaate taga olevad materiaalsus, kehalisus ja tungilisus - kõik see, mida Kivisildnik edaspidi järjekindlalt nimetab loomastumiseks. „(:)raadiopastori” retseptsioon tunnustas Kivisildnikku stiilimeistri ja ühiskonnakriitikuna (vt Kaalep 2012; Oja 2012), kuid kostis ka kahtlevaid hääli: „Saan aru, et oma arvamuse esitamine vastuvaidlemist mittekannatava tõena, pealiskaudsus ja mustvalgus võib olla kirjaniku stiil, peen huumor või mis iganes, aga ma kardan, et selline raadiopastor nagu Kivisildnik külvab rohkem halba, kui lõikab head" (Prints 2012). Viimane seisukoht annab märku karnevali perspektiivi teisenemisest ja tõstatab uued küsimused: kas kogu kommunikatsiooni vallutanud karnevalimudel on veel tähenduslik? Kas sellest tekkiv transgressiivne energia mõjub konstruktiivselt või esteetiliselt? Kes määrab ühe või teise teose konstruktiivsuse astme? 


\section{Räusk}

Sajandi teisel kümnendil on kultuuriliste maskide ja keelemängu vabastav tähendus muutunud märgatavalt ambivalentsemaks. Kui klassikaline karneval leiab aset kindlal nädalal või päeval, mille vältel on lubatud rikkuda ametliku käitumise norme ja kirjutamata kokkuleppeid, siis postmodernistlik kultuuripraktika sisendab, et vaatemäng toimub katkestuseta, pidevalt ja kõikjal. Totaalse karnevaliseerumisega on tugevnenud ka selle juurde kuuluv ebatsensuurne diskursus ja ametliku tava piire ületav keelekasutus. Karnevalile olemuslikud elemendid (mäng, mask jt) on segunenud argitegelikkust vaikimisi reguleerivate nõuetega, nõnda et ühte pole võimalik enam teisest eristada. Loomingu seisukohast tähendab see küsimust kunsti piiridest: kust alates muutub poliitiline protestiesteetika häirivaks ja ebaviisakaks laamendamiseks? See on ka Kivisildniku viimaste aegade loomingulise tegevuse problemaatiline kontekst, mistõttu tema jätkuv transgressiivne praktika ei leia enam kriitikas mõistmist.

Maski kui esteetilise alibi hääbumine on XXI sajandi kasvav trend: väljaütlemiste sõnasõnaline tõlgendus ja identiteediküsimuste poliitiline agenda saavad uudismeediat ja sotsiaalsuhtlust iseloomustavateks tunnusteks. Elektroonilisse meediasse ilmub uutmoodi valitsusvastane hoiak, mille maailmavaateliseks aluseks on kümnendi alguses tekkinud alternatiivse parempoolsuse (ingl alt-right) ideoloogia. See tegeleb ennekõike selliste teemadega nagu läänemaailma demograafiline ja kultuuriline allakäik, nüüdiskultuuri dekadentne olemus, kultuurimarksism, antiegalitaarsus ja islamiseerumine, pakkudes alternatiivi parempoolsete konservatiivide võrdlemisi liberaalsele valitsuspoliitikale. Irooniline, nihilistlik ja anonüümne liberalismivastasus tähendab poliitilise korrektsuse, feminismi, multikultuurse ideoloogia jõulist kriitikat, mille arsenali kuuluvad äärmuslike vahenditena isiklikud solvangud, verbaalne ahistamine, isegi vägistamis- või tapmisähvardused. Kui veel hiljuti kuulus internetistiili juurde dramaatiline ja äratuntavalt veiderdav toon, mis „lunastas” ennast postmodernistlikust esteetikast tuleneva distantsi kaudu nõnda, et seda polnud võimalik otsesõnu tõlgendada, siis nüüd see esteetiline filter enam oluline ei ole (vt Nagle 2017: 10-27). Selle mõjul on tekkinud uus transgressiivsus, mis sisaldab palju vägivaldset ja tumedat energiat ning milles defineeritakse ümber karnevali poliitiliselt süüdimatu olemus, samuti tühistatakse mängu ja elu piirid. Esteetiliselt väljendub see lõhestumine üldises suhtumises kaasaegsesse kunsti: ühelt poolt tabude lõhkumine, vaatemängulisus ja inimkogemuse piiride nihutamine, teisalt küsimus esteetilise vabaduse ulatusest ning eetika ja esteetika vahelise rangema piiri vajalikkusest (vt Stallabrass 2006: 118-120).

Käesoleva artikli keskne argument väljendabki muutunud reaktsiooni: Kivisildniku viimaste aegade looming asetub transgressiivsuse traditsiooni murdepunkti, kus piiriületust ei tajuta enam kunstiliselt tähenduslikuna või kontseptualiseerituna. Kivisildnik ei tegele üksnes XX sajandi avangardistile omaste vormiliste otsingute ega inimkäitumise „hälbe” arvustamisega, vaid esineb järjest enam vastuolulise poliitilise kõneisiku ja publitsistina, liberaalsemale kriitikule ebamugava maailmavaate propageerijana. Seepärast muutub kriitika varasem vaikne nurin kohati irooniaks või tagurluse kahtluseks, 
sest paljude teemade suhtes võimukriitilisele või isiklikult ründavale hoiakule ei ole enam võimalik alati kaasa elada.

Transgressiivse kunsti poliitiline kriitika on alates 1960. aastatest lähtunud konservatiivse maailmavaatega õpetlastest: kontrakultuuri institutsioonidevastane hoiak, destruktiivsus, avameelne seksuaalsus olid tollaste kultuurikonfliktide aines paremtiiva vaatepunktist (vt Nagle 2017: 36-37). See olukord on nüüdseks pöördunud: liberaalsemad kriitikud tajuvad transgressiooni teemades, mis puudutavad rahvastiku või rahvuse probleeme, sugude võrdõiguslikkust ja konservatiivset seksuaalkäitumist jms. Kontrakultuur on nihkunud poliitiliselt teise äärmusse. Kivisildniku karnevali või mängu vormis käsitletavad sigadused ja skandaalid olid kunstiliselt vastuvõetavad niikaua, kuni need pöördusid põlvkonnakaaslaste vastu või kuni neisse ilmus tugev paremale kalduv radikaalne retoorika: „see taplus käib / inimeste ajude ja / südamete pärast // see et enamus / kirjanikke ja kunstnikke / on selle sõja lahingu / väljadelt deserteerinud // ei tähenda seda et seda / sõda ei oleks või et see / sõda ei oleks tähtis" (Kivisildnik 2017a: 19). Kivisildniku moralism vastustab siin liberaalset kultuuripoliitikat ja maailmapilti ning sellest perspektiivist vaadatuna paigutuvad Kivisildniku väljaütlemised kohakuti teiselt poliitiliselt tiivalt lähtuva vastumõtlemisega, mida käesoleva arutluse raames võiks nimetada paremtransgressiivsuseks.

Klassikalise liberaalse maailmavaatega on vastuolus ka paljud Kivisildniku hilisema loomingu lüürilise mina positsioonid või pikemate tekstide protagonisti troobid. Jõulise juhtimise, prohvetlikkuse ja teadmise valdamise hoiak suureneb minaloomes eriti viimase viie-kuue aasta raamatutes. Konservatiivsusse kalduvat tähendust kannab õpetaja kujund ja mõrvar-luuletaja, otseselt kurja ja vägivalla troopi esindavad nt inimsööja taksojuht „Valuraamatu” III köites (2013), Paul Pank „Visa hinge”-seerias (2013-2014) jpm. Maailmavaadet puudutavaid hoiakuid pole autor varjanud:

Puht vormitunnuste järgi ma ei olegi intellektuaal vaid katoliiklik-puutinlik nats (teose „Poeem Puutinile” autor, Argo 2004, Tallinn), sest ma olen anaalseaduse vastu, Eesti Vabariigi põhiseaduse poolt, massiimmigratsiooni vastu, globaliseerumise vastu, ma ei jaga kominterni ega ajatollade terroristlikke ideid ega poolda finantsoligarhia omavoli ega masside vaesumise ja loomastumise poliitikat. Mis intellektuaal nüüd mina, olgem ikka terminites täpsed. Ma pole isegi eestlaste muistsest vabadusvõitlusest lahti öelnud ega kavatsegi seda teha. (Kivisildnik 2015c)

Kivisildniku viimase kümnendi luules ja publitsistikas on süvenenud eriomane räuskav laad (ingl rant), mis on tänapäeva vaste bahtinilikule väljakukõnele ja biitluule teatavatele suundadele, aga ka tänavaluule ja radikaalsete räpparite eneseväljenduse paariline. Hasso Krull on seda nimetanud ka proletaarseks poeetiliseks hoiakuks (vt KPJD: 189-193). See on alati rõhutatult ajalaululine, raevukas enese ja maailma vahelise suhte määratlemine, mille pinnaseks on masendus ja depressiivsus, võimetus olukorda muuta: 
inimesi on tõesti liiga palju toon

veel mõned konkreetsed näited

liiga palju ansipeid vihkan neid

liiga palju miksereid vihkan neid

liiga palju savisaari vihkan neid

liiga palju mart laari vihkan neid

liiga palju munne vihkan neid

liiga palju sitapäid vihkan neid

liiga palju taimetoitlasi vihkan neid

liiga palju kristlasi vihkan neid

liiga palju eurooplasi vihkan neid

liiga palju kastraate vihkan neid

liiga palju idioote vihkan neid

liiga palju demokraate, vihkan neid

liiga palju tarbijaid vihkan neid

liiga palju kurnajaid vihkan neid

liiga palju pankuritest perverte põlgan

liiga palju kirjaoskamatuid jälestan

õhtul pepu pakule mitte padjale sest

selliseid inimesi ei panda padaje

sitaks palju loomastunud pööblit

sitaks palju inimrämpsust mööblit

(Kivisildnik 2017b: 48)

Tegelikkusele reageeritakse väga lihtsustatud kujul, lausung või lausungite seeria rebitakse lahti süsteemsest taustast ja analüütilisest kujundist, nõnda et sõnum võimendub üksikmotiivi(de) kordamise kaudu. Räusa tuumaks on agressiivne väljendusviis, see sisaldab varjamatult vastanduvat hoiakut, lähtudes äratundmisest, et kõik protsessid kulgevad vales suunas. Samas ei pruugi olla välistatud sarkastiline (enese)iroonia, sõnamängud või nimemõnitus (väiketähelisus, mitmus, valestikirjutus, võõrnimede häälduspärane transkriptsioon jms). Seda tundelaadi on Kivisildniku 2010-ndate alguse luules ka märgatud: „[---] üldine vaimne allakäik tekitab teatud vaimse valuimpulsi, mille tagajärjeks pole aga mitte melanhoolia, vaid hoopis raev, poeetiline agressioon" (Kaus 2013: 94). Kõige sellega kaasneb ka lõpliku tõe kuulutamine ja väljaütlemine: „aga prohvetid / löövad sulle / kohe noa selga // nemad teavad / mis tuleb ja / kuidas on vaja" (Kivisildnik 2012a: 54-55). 


\section{Kõrvalepõige: industriaalesteetika}

Transgressiivsuse piiride nihkumise või ümberpaiknemise seisukohalt pakub huvi ka Kivisildniku „tüpoloogiline” sarnasus ameerika muusiku, kirjaniku ja tegevuskunstniku Boyd Rice'iga. 1970. aastatel helikunsti ja poliitika piire ümbermõtestanud eksperimentaalse müramuusika (ingl noise music) klassik, artistinimega NON, hakkas hiljem flirtima valge rassi ülemvõimu jutlustavate liikumiste ja satanismi ideedega, mis kriitikutele enam avastamisrõõmu ei pakkunud (vt nt Hegarty 2010: 120-121). Katsetused tööstusliku või tehnoloogilise müraga on üks osa avangardsest industriaalkultuurist, mis omakorda tuletab meelde, et ka Kivisildnik on teinud eksperimentaalset industriaalmuusikat ansamblis Whaw!Zaiks. Tavaesteetika piire ületava industriaalse iluga on Kivisildniku loomingut seostatud varemgi ning nähtud selle kokkukuuluvust kitsalt kirjandusliku masina või tehnoloogilise printsiibiga: „Ta teeb industriaalkirjandust. Tema meetod on tehnoloogia. Tehnoloogia loob. Kivisildnik jälgib. See, mis lõpuks välja tuleb, on peaaegu seesama mis industrialmuusika. See tundub olevat müra. See ei ole seda absoluutselt mitte. See on hoopiski kõigest liigsest puhastatud. On destillaat. Aga, pole põhjust arvata, et kes industrialmuusikat ei armasta, armastaks selle kirjanduslikku ekvivalenti." (Walden 1996)

1970. aastate teisel poolel kujunenud industriaalkultuuri voolu on iseloomustatud transgressiivset kujutlusvõimet realiseeriva praktikana: „Sellel puudub selgepiiriline ühtne esteetika, välja arvatud see, et kõiki vastikuid, jäledaid, õudseid, nõrgamõistuslikke ja ülekohtuseid asju vaadeldakse läbi musta huumori. Miski pole (ega saa enam kunagi olla) püha, välja arvatud kohustus realiseerida individuaalset kujutlusvõimet." (Vale 2006 [1983]: 2) Industriaalkultuuri vastupanust kultuuritööstusele on sündinud olulisi kultuurikorralduslikke ja poliitilisi hoiakuid, mida võib kohaldada ka Kivisildniku juhtumile, näiteks organisatsiooniline autonoomia, mis kirjanduselus tähendab sõltumatute väljaannete loomist. ${ }^{3}$ Kivisildniku muutumise murdepunktiks võiks pidada 2004. aastal asutatud kirjastust Jumalikud Ilmutused, hiljem on lisandunud kirjastus mm („mine munni”) ja SoundCloudis kuulatav Luuleraadio. Institutsiooniloomega elimineeritakse kontrolliv või tsenseeriv printsiip, mis tagab sõnumi konkreetse maailmavaatelise hoiaku pooldajatele ligipääsu informatsioonile (vt Savage 2006 [1983]). Tänapäeval on kommunikatsiooni küsimus lihtsam: sarnaste veendumustega indiviidid leiavad meelepärase sotsiaalmeedia platvormi või grupi, mis vahendab nende kultuurilis-poliitilisi hoiakuid kinnitavat informatsiooni. Seda võimalust kasutab agaralt ka Kivisildnik, kirjutades, kommenteerides ja vahendades tekste oma Facebooki seinal. Alternatiivsete veendumuste esitamisel ja tabuteemade käsitlemisel nii industriaalesteetikas kui ka transgressiivses kunstis on tähtis koht š o kit a ktik a l - tegevusel või hoiakul, mis kindlustab, et väljaöeldud sõnumit märgatakse (vt Savage 2006 [1983]). Kui jätta praegu kõrvale päevapoliitiline jaur ja jagelemine sotsiaalmeedias, siis ennustab Kivi-

${ }^{3}$ 1990. aastate algusest mäletab Kauksi Ülle: „Ükskord uue kirjanduse arutelul rääkis Kivisildnik uuest kirjastamises, mille toob kaasa arvuti. Arvutis saab iga luuletaja riputada oma asjad võrku, teksti on hea töödelda, kirjastamisel kaovad ülemäärased materiaalsed kulutused ja inimene on vaba." (Kauksi Ülle 2014: 58) 
sildniku viimase kümnendi raamatuluule šokeeriv paatos inimkonna masendavat allakäiku ja vägivallast küllastunud tulevikku.

\section{Jeremiaad}

„Sa ei pea mitte tapma” (2Mo 20: 13). Vägivald ja tapmine on piibliaegadest alates keelatud, kuid sõltuvalt keha poliitilisest tähendusest erinevatel ajastutel siiski teatud tingimustel lubatud. Inimest võib tappa duellil, feodaaltülides või sõjas, kusjuures kaks esimest on ajaloolises plaanis sõja erivormid. Nende juures teadvustatakse keelu olemasolu, kuid rikutakse seda vastavalt täpsetele ettekirjutustele. (Bataille 1986: 72) Modernse sõjadiskursuse tabud on vägivald ja julmus. Sõja ja tabude eriline vahekord seisneb selles, et tabud ei toimi või vägivald ei järgi mingeid piire: „Tabude rikkumiseks vajalikud piirid olid kehtestatud, kuid need olid vaid formaalsed. Agressiivne impulss ei allunud kehtestatud mõjuvõimule.” (Bataille 1986: 78) See kõik puudutab küll militaarsuse antropoloogiat, kuid nimetatud tabud mõjutavad ka sõja kujutamist või sõjast rääkimist. Kirjandus ja filmikunst on viimase poolsajandi vältel tegelenud sõjateemade käsitlemisel paljude piiri ületavate vägivallatroopidega (surm, vigastused, piinamine, vägistamine). Paljuski provotseerivalt töötab militaardiskursusse kuuluvate tabude ja piiridega ka Kivisildnik, rebides sõja teema käsitlemisel esile vägivalla ja hävingu metafoori.

Sõjaolukorra piiride mõju ulatub ka rahuaega, mil sõjast rääkimine võib osutuda paanika külvamiseks või propagandaks. Erandlik kõnelemise õigus on sõjaväelastel ja välispoliitika spetsialistidel. Millises positsioonis on selle teema käsitlemisel kirjanik? Sõjapropaganda on Eestis karistatav „vabadusekaotusega kolmest kuni kaheksa aastani”, nagu määratleb karistusseadustiku riigivastaste kuritegude peatüki $\S 69$. Kivisildnik on kunstilise väljenduse ja sõjapropaganda võimalikust lähedusest teadlik (vt Kivisildnik 2014: 25, 64). Siin tekib otsene võimalik kokkupuude seadusandliku normi ületamisega kunstis. Kuigi transgressioon on tajutav, sest sõja teema elustab kollektiivse mälu traagilised üleelamised või madaldab patriootilist maailmavaadet, on siiski selgelt tuvastatavad esteetilised filtrid, mis tagavad võimaliku üleastumise alibi.

Sõda on Kivisildniku hilisema loomingu läbiv teema, millel on pikemalt peatunud nt Neeme Lopp ja Mart Kangur (vt KPJD: 159-163, 169-171). Masendus ja depressiivsus tipnevad suure sõja või hävingu visioonis: katastroofi üleelamise märgid (varemed, kalmistud, kodutud, taudid) ja sellega kaasnev vägivallalaine (tapatalgud, gladiaatorid, zombid jms) vahelduvad musta huumori või sarkastiliste pildikestega tarbimisühiskonna rahuajast. Kivisildnik saavutab selle haripunkti raamatus „Olovernes. Kaks vaadet elule” (2015a) avaldatud filmistsenaarumis „Kellel on pikem”. Lähituleviku laastatud ja loomastunud Eestit kujutatakse jaburustega mängiva bizarro-esteetika ja oudusfantaasia vastasmõjus tekkiva allegooriana. See meenutab autorihoiakut, mida Julia Kristeva on määratlenud „apokalüptilise naeruna”. See on XX sajandil apokalüpsise- ja karnevalikirjanduse välja vahetanud „abjektse kirjanduse" (vt Kristeva 2006: 201-202) pärisosa, mis kannab endas tabu kirjeldamisest tulenevat „püha õudustunnet”, nt hävinguga kaasneva hirmu ja 
tulevikunägemusest tekkiva lummuse korraga esinemise hallutsinatoorset kujutluspilti (vt Kristeva 2006: 290-293). Kristeva ei pääse mööda piibli eeskujudest ning ka Kivisildniku puhul võib kõnelda ühest väga klassikalisest žanrist - jeremiaadist. See on Vana Testamendi Jeremia raamatule osutav tekstitüüp, eesti kirjanduseski tuttav kaebelaul, maailma ja ajastu kombeid kritiseeriv, inimeste ja jumala suhteid määratlev, manitseva tooniga pikem narratiiv (Cuddon 2013: 377).

Kivisildniku nägemustes on hämarat pühamehe perspektiivi, mõistukõnet ja kummalisi sümboleid, sealhulgas koguste ja numbrite kaudu võimendatud visioone (vt nt Kivisildnik 2012a: 44-45). Prohveti troopi on esile tõstetud ka varasemates kirjutistes (nt Hasso Krull ja Leo Luks, vt KPJD: 70; Luks 2015: 210-213). Kujundlikult kõige tihedama kontsentratsiooni saavutab pühamehe „kõne” „Valuraamatu” teises köites, religioosset kirjandust imiteerivas poeemis „(:)Soari evangeelium” (2012b). Raamatu keskmes on XX sajandi alguses Eestimaal tegutsenud õpetaja ja ajakirjanik Redik Soar, kellest Kivisildnik on kujundanud globaalset allakäiku jutlustava prohveti ja väejuhi. Ta on diktaator ja kanooniline luuletaja, ökoinimeste ja liberaalsete eurooplaste vaenaja, kelle eesmärki pühendavateks vahenditeks on totaalne sõda ja häving. Seeria nimena ühendab „valuraamat” häda, kannatuse ja väljasuremise motiivi metallurgiast tuttava monumentaalsust taotleva vormiga. Eepilisust vahendav prohveti kuju annab fragmentaarsele allakäigunarratiivile tähendusliku vertikaalsuse, samal ajal muudab mäng religioossete fraaside ja tsitaatidega teose ka paroodiaks. Retooriliselt laamendav, kordustesse ja kinnismõtetesse takerduv, ärritab „(:)Soari evangeelium” oma hüperboolsusega, samas on teatud hetkedel kaude või otsesemalt võimalik tajuda pühaduse või korra (rahu, keha, jumala, eetika jne) pimedat või õudset külge: „konutab inimene mere kaldal / sel inimesel on vähk ja ta / veel hoopleb sellega” (Kivisildnik 2012b: 89). Sarnaselt töötavad „Valuraamatu” I köites „Liivlased ja saurused” (2011b) kalmistufotod koos väljasuremise kujundiga: pühaaiale olemuslik õudus suunatakse lihtsa ja argise keelekasutusega, st pühadusele sobimatu otsekohesusega transgressiivsel moel lugeja poole.

Preapokalüptilist manitsust ja postapokalüptilist visiooni ühendab abordi teema, mis juhatab sisse ka rahvuse tulevikku puudutava pessimistliku mõtteviisi. Abordist on tänapäeval saanud poliitiline tabu, aga see on alati olnud üks kriisiajastu klassikalisi kujundeid, mida saadavad kidumise, viljatuse ja ahermaa motiivid. Pikem luuletus „Torti ja aborti” (2007) on abordi äraspidine apoteoos: areneva loote katkestusest saab globaalset allakäiku tähistav kriitiline metafoor, mis jõuab välja „abordiarstide” kujundatud globaalsesse düstoopiasse või ahermaale: „fossiilidest oleks võinud / sündida helge tulevik / aga planeedile / tehti abort / kirkadega / labidatega / ja haamritega” (Kivisildnik 2007: 2). Lüürilise mina olemuseks on „sügav ja vahetu / aborditunnetus" (Kivisildnik 2007: 17), mis ühendatakse omakorda Eestimaa kujundi ja rahvuse tuleviku teemaga. Vaatamata tugevale sõnamängulisele hoiakule on luuletusel kujutlusvõimet ja stabiilsust riivav väljenduslik jõud. Märt Väljataga tõstab Kivisildniku nullindate keskpaigast alates kirjutatud isamaaluuletustes esile just ,"organismi terviklikkust lõhkuvad” kujundid: vägistamised, abordid, verejooksud" (KPJD: 117). 
Kivisildnik ei ole loomulikult klassikalises mõttes sõjakirjanik (nagu nt Ernest Hemingway, Antti Tuuri, Louis-Ferdinand Céline jt), pigem uurib ta teemat meedia vahendatuna („seriaal nagu / iga teinegi”, Kivisildnik 2012a: 50) või preapokalüpsise troobi kaudu, sealt ka eepilisust jäljendav kujutlusvõime ning moralistlik meediat ja massiteadvust ekstrapoleeriv perspektiiv. See on omamoodi kättemaksukirjanduse (vt Undusk 2008) või vimmakirjanduse traditsiooni jätkamine eesti kirjanduses, kuigi vaenlased ei ole enam saksa mõisnikud, vaid globaalsed suurvõimud, kodumaised poliitikud ja tarbimisfantaasiates elav juhm mass. Sellise narratiivi keskmes on hukkuv kangelane, kes oma vastumõtlemise ja tegutsemisega ometi õilistab vältimatut lüüasaamist ja eksistentsiaalset absurdi: „langeda / võib kangelasena / mõnus // õiglase sõja / võib kaotada / pole paha // aga välja surra / saab ainult / värdjana // sõda" (Kivisildnik 2012a: 56). Kuid allakäigu ja hävingu metafoorika koondub sageli blasfeemilise või spirituaalset traditsiooni ohustava keelu ümber. Transgressiivsuse kontekstis on see Kivisildniku maailmavaateliste hoiakute põhipraktika.

\section{Religioon}

Erinevatel aegadel on poliitilise tabudiskursuse oluliseks komponendiks olnud eksitavad või vigased religioonitõlgendused, hereesiad, blasfeemiad jt pühaduse madaldused. Transgressiooni ja religiooni suhe sõltub ajastu usuelu intensiivsusest ja kultuurikontekstist. Globaliseeruva ja sekulariseeruva maailma üheks jooneks on religioosse pluralismi levik ja usukeeldude ning dogmaatika nõrgenemine. Samal ajal tugevnevad konfliktsemaks muutuvas maailmapoliitikas ka religioossed õpetused, selle tõukejõuks on kristluse ja islamiäärmusluse vaheline konflikt (vt Haynes 2009: 4-7). Sajandialguse poliitiliste huvigruppide ja aktivistide poolt ülesköetava moraalse paanika üheks väljundiks on suurema tähelepanu osutamine religioossetele ideedele ja neid esindava ikonograafia kasutamisele lääne kultuuris. Kui 1990-ndatel ei pälvinud religioossed probleemid Eestis poliitilist tähelepanu, siis praeguseks on need vahekorrad teravamaks muutunud. Näiteks Eesti Rahva Muuseumi installatsioon neitsi Maarja kujutisest, mida oli võimalik jalaga lüüa, tekitas omajagu vastakaid reaktsioone (vt Kohler 2016). Samal ajal demonstreeris see juhtum euroopaliku kultuurisõja klassikalist tasandit - rahvuse ja kristliku müüdi kokkukuulumist. Kui Kivisildnik töötas 1990. aastal ajalehe Vagabund toimetajana, ilmus seal tema kirjutatud deklaratsioon pealkirjaga „Hüübinud vere manifest”, millele „Islamirevolutsiooni nimel” olid alla kirjutanud paljud tollased ärksad noorepoolsed kultuuriinimesed. Kivisildniku religioossete motiivide üksteise vastu väljamängimine ning kristluse padukriitika jätkus hiljem ajalehtedes Kostabi ja Post. Praeguses olukorras nähtaks sellistes kristlikku traditsiooni õonestavates vihakõnedes või vägivallale õhutavates pamflettides poliitilist propagandat.

Postmodernse transgressiivsuse ja religiooni piire on Kivisildnik kompinud ka XXI sajandil. Üks kontseptuaalne katsetus on Rainer Maria Rilkega „koos” tehtud poeem „(:)Joosepi kahtlused” (2008). Tegemist on Jeesuse elulooga, religioosset temaatikat käsitleva suure modernistliku teksti kaasajas- 
tatud tõlgendusega, samal ajal postmodernistliku ja minimalistliku religiooniparoodiaga. Autor ütleb saatesõnas, et see on „originaali” ehk ilmutuse tõlge, mis tähendab tänapäevale kohandamist. Nt Jeesuse sünni peatükk „Geburt Christi” on tõlgitud „abort ebaõnnestub”: „lihtsus valgustab ööd / iidne uudisteankur / müristab spordikanalil // maailmameistrid / lohistavad maarja rüppe / kõik oma medalid // võistlusnaelikud ja / tagaotsitavad tabletid / jeesus sünnib siiski" (Rilke, Kivisildnik 2008: 20-21). Leo Luks on selle tekstikoha ühendanud hävingu teemaga ning tõlgendanud seda utoopilise maailmaloomise ennetamisena ja lunastussõnumi ümbermõtestamisena (vt Luks 2015: 217-218). Transgressiivse nüansi lisavad ,ilmutuslikule” projektile Andres G. Adamsoni fotod ja kujundus, kus kasutatakse fragmente BDSM-episoodidest ja sidumisseksi esteetikast. See teeb religioosse üleastumise kehaliseks, valu ja naudingut ülendavaks kogemuseks. Pühaduse või transtsendentse väljendamine seksuaalvahekorra markeerimise või kujutamise kaudu on Kivisildniku usukriitikale ka üldiselt tunnuslik. „(:)Joosepi kahtlustele” annab lisavindi teksti lõpus olev dateering ja koht: „pärnu adolf hitleri nimeline raamatukogu 16. märts 2008. a."

Kui klassikalise kristluse paroodiad ei kanna eesti ateistlikus nüüdiskultuuris enam väga tugevat transgressiivset tähendust, siis paralleelselt tegutseb Kivisildnik palju ambivalentsemate tõlgenduste suunal. Kristlikku headusreligiooni ja kiriku institutsiooni kritiseeritakse mitmel juhul Friedrich Nietzsche eeskuju alusel, kuid Kivisildnik liigub sealt edasi uususundite radadele. ${ }^{4}$ Kui 2008. aastal avaldati Anton Szandor LaVey „Saatanliku piibli” kolmas eestikeelne trükk, siis raamatu vahel eraldi lehel ilmunud kaassõna autoriks oli just Kivisildnik. Lühikeses essees pealkirjaga „(:)Saatan ilma maskita” ei rõhutata mitte satanismi massikultuurilisse teadvusse jõudnud rituaale ja „maske”, vaid tavainimese ratsionaalseid valikuid ja loomulikke instinkte: „Kindlasti meeldib sulle teha seda, mida ise tahad. Vaevalt sa usud reklaame, poliitikute valesid ja pappide libekeelseid meelitusi. Sulle ei meeldi käte väänamine, vaimu nüristamine ja olukord, kus sind koheldakse debiilse koduloomana. Võib-olla sa isegi mõtled vahel. Kui jah - siis oled sa kindlasti satanist." (Kivisildnik 2008) Siit ei leia mingit transgressiooni, millele annaks kohaldada karistusseadustikku, kuid ometi annab elus läbilöömise juhisena tõlgendatud satanism üldise võtme mõistmaks Kivisildniku provokatiivset ja ülbitsemisena mõjuvat käitumist. Religioosse satanismi akadeemilistes kirjeldustes on satanism eelkõige postkristlik mõtteviis, kus saatan assotsieerub seksi, uhkuse, mittekonformismi, mässulisuse ja individualismiga. Satanistlikus diskursuses ja praktikates tõstetakse esile tugevat eneseusku, mis keskendub mõjuvõimule, enesetunnetusele, tegelikkusetajule, mina maksmapanekule ja avaldub näiteks ratsionaalse enesekesksuse, elitaarse salateadmise poole püüdlemise või oma loomuliku võime arendamisena. Mina manifesteerivat maailmapilti pole ometi võimalik mõista ilma negatiivse küljeta, mis väljendub välistest autoriteetidest distantseerumises või destruktiivses hoiakus nende suhtes, väljakujunenud normide ja jõugumentaliteedi õonestamises. Sealjuures pole see mittekonformistlik hoiak seotud üksnes kristlusega, vaid see on üldine vastuolek traditsioonilistele ja modernsetele võimu-

\footnotetext{
${ }^{4}$ Varasema kohta vt nt Kauksi Ülle 2014: 79 või Kivisildnik 1997: 2.
} 
institutsioonidele. Kristlust mõistetakse küll totalitaarse ja moraalselt rõhuva jõu näitena, kuid sellele lisanduvad teised vaenlased: tarbimisühiskonna diktaat ja passiivne meelelahutuskultuur, liberaalse ühiskonna inimõigused ja võrdsuse idee, puritaanlik seksuaalmoraal jne (Petersen 2009: 2-3). Kuigi see kõik on nominaalselt seotud kristlusega, on saatana sümbol satanismis väga mittetraditsiooniline; siin tekivad paralleelid Nietzsche üliinimese kujundi ja radikaalse antikristlusega (Petersen 2009: 3).

Need positsioonid on tagasiviidavad ka artikli alguses mainitud romantilise mässaja tüübile. Kivisildniku religioossed transgressioonid on „sektantlike voolude" - judaismi, kristluse ja islami - õpetuste ümberkirjutamine, mis pealispindselt avaldub tsitaatide ja vormelite paroodiana, kuid ulatub ka nendesse kriitilistesse tekstidesse, kus pühadusega otseselt ei tegeleta või satanismi troopi äratuntavalt ei kasutata. Kõik eeldused vastumõtlemiseks on kapitalistlikus ühiskonnas olemas, kuivõrd tegemist on ideoloogiaga, kus individuaalsuse manifestatsioonid käivad kõrvuti masside ja materialismi ideedega: „Kui vaatame kogu seda egoismi ja materialismi, mis meie ümber möriseb, on selge, et satanismil ei ole alternatiivi. Valida on teadliku ja vaistliku kuradikummardamise vahel. Valik on sinu. Saatan ilma maskita, see oled sina ise." (Kivisildnik 2008)

Kõige reljeefsemal kujul tutvustatakse „teadliku satanismi” ideed pentagrammide ja satanistliku ikonograafiaga ehitud teoses „Seitsmes Moosese raamat. Eneseabi-nõiaraamat maagidele ja maagia ohvritele" (2015b). Seda võiks lugeda praegusaja eneseabiõpikute ja uue vaimsuse kirjanduse naeruvääristamisena konkreetsete žanrivõtete ja ideede äärmusse arendamise kaudu. Kuid lollitamise ja provotseerimise alla ei kuulu ülalkirjeldatud satanistlik „tundekasvatus". Seega on Kivisildniku lemmikprotagonist või lüüriline positsioon Nietzsche üliinimest meenutav poeedist mõrvar, agressiivselt tarkuslausetes kõnelev äärmuslane ja fanaatik, kellele võib kaaslasi leida autori teistestki tekstidest („Nagu isane kass ümber isase pudru”, „(:)Soari evangeelium” jt). Kujundlikku pinget kannab tapmise motiiv, kuid seda ei mõtestata mitte süüteo või karistuse kontekstis, vaid rituaalse inimohvri kaudu, mis teose allegoorilisel tasandil tähendab iseendas peituva nõrga humanisti ületamist. Teose teine pool sisaldab loitse ja praktikate kirjeldusi, mille eesmärgiks on väe valdamine ja „liiginimlike” nõrkuste ületamine. Loitsude keskmes on vägivaldsete stseenide kujutlused, mille adressaadiks on „maagiaga vusserdajad”, st väge mittevaldavad isikud. Saladuse ja väe valdamise ideed rõhutab ka ikooniline pealkiri: „Seitsmes Moosese Raamat” on nõiaraamat, keelatud raamatu sümbol, müstifikatsioon, mis legendi järgi sisaldab „suurt tarkust” või maagilist teadmist (vt Oinas 1994: 80-81). Kivisildnik on selle vormi täitnud tarkust ja tugevust kummardava minareligiooni jutlustamisega, mille tuumaks on ülima teadmise poole püüdlemine ehk gnoosis.

2019. aasta alguse seisuga viimastes teostes tugevneb järjest „sarvedega humanismi" (Dyrendal 2007: 25, tsit: Petersen 2009) printsiip ja artikli alguses mainitud traditsioonilise karnevali formaat hõreneb veelgi. Raamatute „Kehakultus” (2017c) ja „Ma olen siga” (2018) keskne ideaal on füüsiline ja suguline võimekus, ka füüsiline vastupidavus ja treening. Tekste illustreeriv pildivalik üksnes võimendab seda: „Kehakultuses” on lisaks erootilisele ja pornograafilisele visuaaliale ka keha anatoomilisi kujutisi, tehisinimeste 
pilte, mis on teravalt vastandatud grotesksele ja vigasele kehale. Poliitiline vastandus ideaalse proportsiooni ja groteskse diskursuse vahel, kõrge ja madala vahel on järsk ning jäägitu, mistõttu see keha ei paigutu enam lihtsalt lõbusa, „läbirääkimiste” ruumiks oleva karnevali konteksti. Kui asetada „kvaliteetkeha” ja „kehakultus” uussatanistlikku konteksti, siis muutub Kivisildniku kinnismõttelisena mõjuv käsitlusviis mõistetavamaks. Kristlikule õpetusele ühiselulisest ja „nõrgast”, madala enesehinnanguga indiviidist vastandab satanistlik maailmavaade jõulise või tugeva indiviidi kontseptsiooni, mis tähendab uhkust, ambitsioonikust, enesekeskset ja enesekindlat subjekti (Mørk 2009: 178). Tugevus väljendub loomulikult ka keha teistsuguses mõtestamises ja tarbimisühiskonna kehaideaali kriitikas. Kehal on mina puhastumise ja ümbermõtestamise funktsioon ning keha on intiimseim minaelement, st meie eksistents sõltub otseselt kehast. Keha tähtsustamine mina muutmise ja väljendamise seisukohalt on seotud maskuliinsuse teemaga: keha on vahetu ja võimas meheliku energia allikas. Sealt edasi toimub meheliku identiteedi konstrueerimine läbi transgressiivse kehalise praktika, millega kaasneb see, et samal ajal eraldatakse ennast rohkem või vähem üldlevinud kultuurinormidest (Mørk 2009: 192). Sellega on põhjendatud Kivisildniku teostes esinevad erinevad vägivalla vormid, „Seitsmenda Moosese raamatu” tapmise motiiv, läbivad osutused seksuaalsele „vallutusele” jms, mis manifesteerivad kehalist maskuliinsust, selle energiat ja reaalsust. Kusjuures Kivisildnik ei hülga poeedi positsiooni ning keha on loomingu ja vaimse sfääri loomulik osa: „täpsustan ma mõtlen / kompositsiooni ja kujundi / all oma kvaliteetkeha” (Kivisildnik 2017c: 20). „Teadliku keha” või maskuliinsuse ideed võiks kinnitada kaks eri allikatest pärit näidet, millest esimene on katkend briti satanisti Vexen Crabtree tekstist „Ihu religioon”: „Juhised Tulest, kuula neid Saatana sõnu! / Liiguta oma keha nagu masin. Treeni oma keha. / Ära ole ülekaaluline ameeriklane või osake paksude inglaste suurenevast hulgast. / Ära ole füüsiliselt nõrk arvutikasutaja. / Valluta maailm.” (Crabtree 2009: 234) Ja teine: „minu keha ei / ole sotsiaalne / konstruktsioon // minu keha on / minu looming // minu vaimujõu / apoteoos // minu keha on / minu au väärikuse / südametunnistuse // nagu ka jultumuse / kontsentreeritud / väljendus // st keha on / ilus ja tugev / see on klassika // sinu kärbunud lihased / ja pekk on sotsiaalne / konstruktsioon // seda küll" (Kivisildnik 2017c: 21).

Treenimise ja seksuaalse võimekuse motiiv läbib ka raamatu „Ma olen siga" kohati üllatuslikult eraelulisse temaatikasse kalduvaid tekste. Pealkirjakujund siga on aga semiootiliselt väga ambivalentne tähistaja, mis sobib suurepäraselt kokku võtma Kivisildniku suhtumist religioossesse ja ilmalikku tabusse. Judaismis on siga räpane või ebapuhas loom (3Mo 11: 7, 8), kristlikus kontekstis seostub see kurjade vaimude ja patuga (Mk 5: 9-16). Kivisildniku vastasseis kontrolliva ja patust kõrvale suunava kiriku institutsiooniga jätkub ka kristliku eetikaga läbipõimunud ilmalikus paradigmas. Juba XVII sajandist alates assotsieerub siga järjest enam kodanliku rünnakuga heade kommete vastu: rustikaalse matslikkusega, millest korralikud kodanikud peaksid kõrvale hoidma (vt Stallybrass, White 1986: 50-52). Neid üleastumisi on määratud korrigeerima poliitilised ja majanduslikud süsteemid, hariduslikud-kultuurilised arusaamad jms. Kivisildnik pöörab tabu rikkumise süüdistuse tagurpidi, tuues taas nähtavale keelu poliitilise, repressiivse ja piiratud 
tähenduse. Selline inversioon pole üksnes enesealandamise kaudu ülenemise mehhanism või hierarhiate ja autoriteedi vastu sõdimise mudel, vaid ka protsess, kus madal sotsiaalne staatus ja sümboolne võim pööratakse nende vastu, kes asuvad süsteemis veel allpool (Stallybrass, White 1986: 53). Kivisildnikul on selleks alamaks kategooriaks „loomastunud” mass, nõrgad, telekavaatajad, sotsiaalmeedias passijad jt.

\section{Kokkuvõtteks}

Loodetavasti annab see Kivisildniku transgressiivsete aspektide kriitiline inventuur koherentsema arusaama, milline on Kivisildniku vastuolulise loomingu või antiesteetika positsioon erinevate kultuuriliste tabude käsitlejana XXI sajandi kahel esimesel kümnendil. Kivisildniku põhivõtted - erandinimese positsioonilt lähtuv provokatiivne solvamine ja sõimlemine - on üldjoontes samaks jäänud, kuid lisandunud on uusi teemasid ning teistsuguse perspektiivi tingib ka muutunud ühiskondlik-poliitiline kontekst. Süüdimatu karnevalimeeleolu on välja vahetanud allakäiku ja hävingut kuulutav jeremiaad, mille lähteseisundiks on depressiivne-realistlik maailmavaade ning mis pingelise maailma- ja sisepoliitika foonil võib mõjuda kahtlaselt ja vaenu õhutavana. Kuigi peaaegu kõik institutsionaalsed suhted (nt kirjanduselu) ja tavanormid (avaliku suhtlemise koodid) on tühistatud või ümber kujundatud (oma kirjastused), võimaldab see lahtiühendatus ignoreerida sotsiaalse kommunikatsiooni kokkuleppeid ja rääkida kultuurilistel ja sotsiaalsetel tabuteemadel. Samas takerdub Kivisildniku viimaste aegade transgressiivne hoiak avalikus meediaruumis levinud ebatsensuurse ja vihase retoorika normiks muutumisse. Poliitilisi ja kultuurilisi äärmusi väljendav parempoolne transgressiivne retoorika ei luba Kivisildniku „kunstilisel nihilismil” või „mängul” enam reljeefselt mõjuda ning kohatine sobimatu ülbitsemine tundub vasakule kalduva liberaalse peavoolu kontekstis poliitiliselt ebakorrektne. Kogu selle provokatiivsuse keskmes on varasemast tugevam minakujund, ülienesekindel ning vaimset ja järjest enam ka füüsilist suveräänsust deklareeriv kirjanduslik protagonist. Kivisildniku vastuolud liberaalse tarbimiskapitalismi mõjudega ja poliitiliste seisukohtadega on kokkuvõttes konflikt lääne kristliku kultuuri põhialustega. Nende vastuolude juured on subkultuuride ja uususundite, nt industriaalesteetika ja satanismi viljeldavas kultuurinormide ümberkirjutamises, kus üleastumine võib olude ja normide muutudes ehmatada totalitaarse kujundi või vihakõne vormis räuskamisega. Kivisildniku transgressiivne teos polegi alati „kultuuripilti avardav” taies või mõne poliitilise võimu kehtestatud tabu tühistamine vabaduse ja progressi huvides, vaid vastupidi - „seakeeramine", mis võib rikkuda aktuaalsete teemade ümber vaikimisi kujunevat retoorikat ja stagneeruvaid suhtlusnorme. Ütlematagi on selge, et see võib olla ebameeldiv, tülgastav ja isiklikult puudutav, aga see on piiride ületamise tänapäev ja reaalsus. 


\section{Kirjandus}

Bahtin, Mihhail 2017. François Rabelais' looming ja keskaja ning renessansi rahvakultuur. Tlk Mall Jõgi. (Avatud Eesti raamat.) Tartu: Ilmamaa.

Bataille, Georges 1986. Erotism. Death and Sensuality. San Francisco: City Lights Books.

Cashe11, Kieran 2009. Aftershock. The Ethics of Contemporary Transgressive Art. London-New York: I. B. Tauris.

Crabtree, Vexen 2009. Reflections on Satanism. - Contemporary Religious Satanism. A Critical Anthology. Toim Jesper Aagaard Petersen. Surrey-Burlington: Ashgate, lk 231-238.

C u d d o n, John Anthony 2013. Dictionary of Literary Terms and Literary Theory. Chichester-Malden-Oxford: Wiley-Blackwell.

D a y, Aidan 2001. Romanticism. The New Critical Idiom. London-New York: Routledge.

Dy r en d a l, Asbjørn 2007. Satanismens historie. - Humanist, nr 1, lk 4-34.

Frye, Northrop (toim) 1963. Romanticism Reconsidered. New York-London: Columbia University Press.

Gournelos, Ted, Gunkel, David J. 2012. Introduction. Transgression Today. Transgression 2.0. Media, Culture, and the Politics of a Digital Age. Toim D. J. Gunkel, T. Gournelos. New York-London: Continuum, lk 1-24.

Has s elblatt, Cornelius 2015. Totalitarismi hilisjärelmid. Üks joonealune märkus eesti kirjandusloole. - C. Hasselblatt, Eemalt vaadates. (Studia litteraria Estonica 15.) Tartu: Tartu Ülikooli Kirjastus, lk 37-41.

H a y nes, Jeffrey 2009. Introduction. - Routledge Handbook of Religion and Politics. Toim J. Haynes. London-New York: Routledge, lk 1-7.

He g a rty, Paul 2010. Noise/Music. A History. New York-London: Continuum.

Ka a le p, Tõnu 2012. kivisildnik. (:)raadiopastor. - Eesti Ekspress 2. II, lk 37.

Kaiser, David Aram 2004. Romanticism, Aesthetics, and Nationalism. (Cambridge Studies in Romanticism 34.) Cambridge: Cambridge University Press.

Ka u ks i Ülle 2014. Ülim tõde. Saarde-Pärnu: Ji.

Ka u s, Jan 2013. Meisterlik seestunu. - Vikerkaar, nr 9, lk 94-97.

Kivisild nik 1996. Nagu härjale punane kärbseseen. [Tartu]: Eesti Kostabi Selts.

Kivisildnik 1997. Loomade peal katsetatud inimene. Romaan. Tartu: Brain Publishing.

Kivisildnik 2004. Null tolerants. Pärnu-Tallinn: Tegelikkuse Keskuse Raamatukogu.

Kivi sild nik 2007. Torti ja aborti. Kohustuslik kirjandus gümnaasiumi astmele. Pärnu: Ji.

Kivisildnik 2008. (:)Saatan ilma maskita. - Anton Szandor LaVey, Saatanlik piibel. Tlk Henri Kuuse, Heija-Liis Kaljuste. Eessõna autor Peter H. Gilmore, lisalehe kaassõna kirja pannud Sven Kivisildnik. Laadi [Pärnumaa]: Algol Publishing, [pagineerimata lisaleht].

Kivisildnik 2011a. (:)raadiopastor. Pärnu: Ji.

Kivisildnik 2011b. Liivlased ja saurused. Valuraamatu I köide. Pärnu: Ji.

Kivisildnik 2012a. Enne sõda ja kõike seda. Pärnu-Saarde: Ji.

Ki vi sild nik 2012b. (:)Soari evangeelium. Valuraamatu II köide. Saarde-Pärnu: Ji. Kivisildnik 2014. Laulurahvas hakkas mõtlema. Pärnu-Saarde: Ji. 
Kivisildnik 2015a. Olovernes. Kaks vaadet elule. Pärnu-Saarde: Ji.

Kivisildnik 2015b. Seitsmes Moosese raamat. Eneseabi-nõiaraamat maagidele ja maagia ohvritele. Saarde-Pärnu: Ji.

Kivi sild nik 2015c. (:) kas savisaar või anaalsed intellektuaalid? - Õhtuleht 4. XII.

Kivisildnik 2017a. Pariis 1911. Ji.

Kivisildnik 2017b = (:)esteet kivisildnik. Kirsiõis 007. [Pärnu]: mm.

Kivisildnik 2017c. Kehakultus. (mm 8 (mustvalge).) [Pärnu]: [Jumalikud Ilmutused].

Kivisildnik 2018. Ma olen siga. (mm 12 (mustvalge).) [Pärnu]: [Jumalikud Ilmutused].

Kohler, Vilja 2016. ERMi kirgi küttev eksponaat: jalahoop Neitsi Maarjale. Tartu Postimees 2. X.

KPJD 2016 = Kivisildnik, põhjendamatu järjekindluse dogmaatik. (Etüüde nüüdiskultuurist 6.) Koost, toim Neeme Lopp. Tallinn: Tallinna Ülikooli humanitaarteaduste instituudi Eesti kirjandus- ja kultuuriuuringute keskus, Eesti Kunstiakadeemia kunstiteaduste ja visuaalkultuuri instituut.

Kraavi, Janek 2016. Transgressiivse kirjanduse poeetikast I. Näiteid eesti nüüdiskirjandusest. - Keel ja Kirjandus, nr 11, lk 817-833.

Kr a a vi, Janek 2017. Obstsöönsuse poeetika ja seksuaalsuse representatsioon I. Kujund ja narratiiv. - Vikerkaar, nr 12, lk 42-66.

Kristeva, Julia 2006. Jälestuse jõud. Essee abjektsioonist. Tlk Heete Sahkai. Tallinn: Tänapäev.

Lister, Martin, Dovey, Jon, Giddings, Seth, Grant, Iain, Kelly, Kieran 2009. New Media. A Critical Introduction. Second Edition. London-New York: Routledge.

Luks, Leo 2015. Nihilism ja kirjandus. Ei kogemine filosoofia ja kirjanduse ühtesulamisel. (ACTA Universitatis Tallinnensis. Humaniora.) Tallinn: Tallinna Ülikooli Kirjastus.

Mørk, Gry 2009. „With my Art I am the Fist in the Face of god”: On old-school black metal. - Contemporary Religious Satanism. A Critical Anthology. Toim Jesper Aagaard Petersen. Surrey-Burlington: Ashgate, lk 171-198.

Nagle, Angela 2017. Kill All Normies. The online Culture Wars from 4chan and Tumblr to the Alt-right and Trump. Winchester-Washington: Zero Books.

Oinas, Felix 1994. Kalevi tarkuseraamat. - F. Oinas, Surematu Kalevipoeg. (Keele ja Kirjanduse raamatusari 1.) Tallinn: Keel ja Kirjandus, lk 77-89.

Oj a, Arno 2012. Issanda koerad raamatu sees. - Sirp 2. III, lk 7.

Parikka, Jussi, Sampson D. Tony (toim) 2009. The Spam Book. On Viruses, Porn, and Other Anomalies from Dark Side of Digital Culture. Cresskill, NJ: Hampton Press.

Petersen, Jesper Aagaard 2009. Introduction: Embracing Satan. - Contemporary Religious Satanism. A Critical Anthology. Toim J. A. Petersen. Surrey-Burlington: Ashgate, lk 1-24.

Pilv, Aare 2016. 90ndad. Pisut loba kirjandusest. - Müürileht, nr 53, lk 24.

Pr in t s, Kairi 2012. kivisildnik. (:)raadiopastor. - Eesti Ekspress. Areen 6. IX, lk 40.

Rilke, Rainer Maria, Kivisildnik 2008. (:)Joosepi kahtlused. (Ji klassika.) Pärnu: Ji.

Savage, Jon 2006 [1983]. Introduction. - Industrial Culture Handbook. RE/ Search \#6/7. Toim V. Vale. San Francisco: RE/Search Publication, lk 4-5. 
Stallabrass, Julian 2006. Contemporary Art. A Very Short Introduction. New York: Oxford University Press.

Stallybrass, Peter, White, Allon 1986. The Politics and Poetics of Transgression. London: Methuen.

Un d u s k, Jaan 2008. Eesti lugu: Eduard Bornhöhe „Tasuja”. - Eesti Päevaleht 31. X. Vale, V. (toim) 2006 [1983]. Industrial Culture Handbook. RE/Search \#6/7. San Francisco: RE/Search Publication.

Vihik esitleb: Eesti uuem kultuurilugu 2004. „On see komöödia? On see tragöödia?" - Vihik, nr 8, lk 31-60.

W ald en, Andreas 1996. Assotsiatiivik. - Postimees 8. VII, lk 18.

Janek Kraavi (snd 1972), MA, eesti kirjanduse õppejõud Tartu Ülikoolis (Ülikooli 16, 51014 Tartu), janek.kraavi@ut.ee

\section{The transgressive Kivisildnik as of 2019: some points of importance}

Keywords: transgressive literature, contemporary Estonian literature, carnival 2.0, religion, jeremiad, rant, right-wing transgressiveness

Transgressiveness has always been one of the pivotal apects of Kivisildnik's creative project. Challenging taboos, a provocative attitude and the standpoint of an exceptional person are still essential for Kivisildnik's recent poetry and publicist prose, but the changed political context and the impact of the new media now lends a different perspective to many of his themes, topics and tropes. The transgressive carnival trope described by Peter Stallybrass and Allon White has been replaced by a jeremiad announcing ruin, based on a depressive-realistic worldview conveyed by exhortational and allegoric visions of catastrophe. Yet today Kivisildnik's transgressive attitude seems to be losing its strength to the obscene and hateful rhetoric which has become the norm in the public media. The right-wing transgressive rhetoric voicing political and cultural extremes robs Kivisildnik's "artistic nihilism" from its protruding quality and makes it sound, in the context of left-leaning liberal criticism, politically incorrect and out of place. The rant building up in Kivisildnik's texts over the past decade is reminiscent of a fierce square speech or the aggressive protest of some radical rappers. At the heart of Kivisildnik's right-wing provocative attitude we find a literary super confident protagonist with an even stronger ego, who declares his mental and physical sovereignty. Kivisildnik's ironical and nihilistic lyrical self is opposed to the liberal and global ideas of consumer capitalism, critisises the demographic and cultural decadence of Estonia and the Western world, and attacks the principles of a multicultural society. Liberal ideology is counterbalanced by the powerful post-Christian thinking of the neo-religions, in which the self-image is associated with the idea of masculinity and sex, individual pride, non-conformism, and supreme knowledge. The transgressive meaning of the above attitudes manifests itself in the reversal of a stagnant world description and in aggressive rhetorical exaggeration, which can be at times unpleasant, disgusting and personally upsetting.

Janek Kraavi (b. 1972), MA, University of Tartu, lecturer on Estonian Literature (Ülikooli 16, 51014 Tartu), janek.kraavi@ut.ee 